Bangladesh J. Bot. 44(4): 565-570, 2015 (December)

\title{
POTENTIAL VALUE OF RED AND BROWN SEAWEED FOR SUSTAINABLE BIOETHANOL PRODUCTION
}

\author{
RagaA A Hamouda*, Mervat H Hussein ${ }^{1}$ and \\ NOURA EL-AhMAdY EL-NAGgaR ${ }^{2}$ \\ Microbial Biotechnology Department, Genetic Engineering and Biotechnology \\ Research Institute, University of Sadat City, Egypt
}

Key words: Brown algae, Red algae, Acid and base hydrolysis, Fermentation, Bioethanol

\begin{abstract}
Algae are renewable sources of feedstock for bioethanol that can be grown on non arable lands, non productive water sources and inexpensive culture systems. Red seaweed Laurencia obtusa and brown seaweeds Cystoseira compressa, Colpomenia sinuosa were analysed by determining sugar content by HPLC and converted into suitable fermentable feedstock by $\mathrm{NaOH}, \mathrm{H}_{2} \mathrm{SO}_{4}, \mathrm{HCl}$ and $\mathrm{H}_{3} \mathrm{PO}_{4}$ at concentrations 1,2 , 3,4 and $5 \%$ at $21^{\circ} \mathrm{C}$ of 20 minutes. The efficiency of hydrolysis significantly improved by $5 \% \mathrm{HCl}$ for Laurencia obtusa at $42.84 \mathrm{~g}$ sugar/100 g dry biomass. Pretreatment of Cystoseira compressa and Colpomenia sinuosa with 3 and $5 \% \mathrm{H}_{3} \mathrm{PO}_{4}$ gave higher sugar content of 30.51 and $41.34 \mathrm{~g} / 100 \mathrm{~g}$ dry biomass, respectively. A relatively high level ethanol of $0.146 \mathrm{~g} / \mathrm{g}$ dry biomass of Laurencia obtusa was produced. Results indicate that Cystoseira compressa and Laurencia obtusa can be good feedstocks for bioethanol production.
\end{abstract}

\section{Introduction}

Population outburst together with increased motorization has led to an overwhelming increase in the demand for fuel (John et al. 2011). Either microalgae or seaweeds could be used for solar energy conversion and biofuel production (Ross et al. 2008). Algae contain complex long-chain sugars (polysaccharides) in their cell walls. The cell walls account for a large production of the carbon contained in these organisms (Singh et al. 2010). Kelp as a rule contains approximately 60 $\%$ carbohydrates of the dry weight. Laminaran (a glucose polymer) and mannitol are energy storage compounds, resembling starch of inland plants, while alginates are structural compounds and correspond to cellulose and lignin in land plants (Kraan 2010). The amount of bioenergy produced by the biomass of red algae is greater than any other source of biomass (Wi et al. 2009). Carbohydrate contents of red algae Pachymeniopsis lanceolata and Gelidium elegans were 60.1 and $51.3 \%(\mathrm{w} / \mathrm{w})$, respectively (Kang et al. 2010). Algae offer a unique alternative biomass feedstock as it lacks lignin that make the release of the fermentable sugars easier and does not compete with agricultural food production (Roesijadi et al. 2010). Brown seaweeds may have a high content of easily degradable carbohydrates, making them a potential substrate for the production of liquid fuels (Horn et al. 2000a). Production of bioethanol requires three steps; a saccharification of raw material, a fermentation, and a distillation. Pretreatments such as chemical treatment, thermal treatment, and enzyme treatment are used in the saccharification process (Truus et al. 2001). One of the most common chemical pretreatments is adding sulfuric acids, that resolve hemicelluloses as well as low cost and high reaction, and no acid-recovery system is required

*Author for correspondence: <ragahom@yahoo.com>. ${ }^{1}$ Botany Department, Faculty of Science, Mansoura University, Egypt. ${ }^{2}$ Department of Bioprocess Development, Genetic Engineering and Biotechnology Research Institute, City for Scientific Research and Technological Applications, Alexandria, Egypt. 
(Esteghlalian et al. 1997). Treatment of biomass with sodium hydroxide causes the disruption of H-bonding in cellulose and hemicelluloses (Simpson et al. 2003). The liquid stream obtained during acid and alkaline pretreatment likely contained fermentable sugar and inhibitory substances released from the breakdown of hemicelluloses (Ohgren et al. 2006). It is, therefore, necessary to develop saccharification processes of seaweeds feedstocks for bioethanol production. The objective of this study was to investigate the possibility of conversion of three seaweeds to ethanol via acid and base hydrolysis and fermentation.

\section{Materials and Methods}

Laurencia obtusa and Cystoseira compressa were collected from Red Sea coast at Safaga, while Colpomenia sinuosa from Mediterranean Sea coast at Abo Quar in May, 2012. After collection, algae were thoroughly washed with fresh seawater, air-dried under shade and oven dried at $60^{\circ} \mathrm{C}$ for $5 \mathrm{hrs}$ and ground to fine dried powder.

The fine-dried powder algae were hydrolysed in 1, 2, 3, 4 and $5 \%$ of $\mathrm{NaOH}, \mathrm{H}_{2} \mathrm{SO}_{4}, \mathrm{HCl}$ and $\mathrm{H}_{3} \mathrm{PO}_{4}$ by ratio of $1: 10(\mathrm{w} / \mathrm{v})$. The hydrolysates were autoclaved at $121^{\circ} \mathrm{C}$ for 20 min., and pressed through cheesecloth. Reducing sugar concentration was estimated by the phenol-sulphuric acid method (Krishnaveni et al. 1984).

Saccharomyces cerevisiae was used for ethanol production. The strain was stored in potato agar slants at $4{ }^{\circ} \mathrm{C}$. For the preparation of inoculum, a loopful of $S$. cerevisiae was transfered from agar slants into $250 \mathrm{ml}$ Erlenmeyer flasks containing $100 \mathrm{ml}$ of sterile culture medium. The flasks were incubated in a rotary shaker at $30^{\circ} \mathrm{C}$ for $48 \mathrm{hrs}$ at $150 \mathrm{rpm}$.

The identification and quantification of the sugars were done by high-performance liquid chromatography (HPLC). The algal extraction were performed with HPLC (Agilent 1100 HPLC system) using an Hypersil ASP-2 column $(4.6 \times 250 \mathrm{~mm})$ with a mobile phase of acetonitrilewater $(80: 20)$ at a flow rate of $0.4 \mathrm{ml} / \mathrm{min}$. The temperature of column and optical unit were set at 35 and $40^{\circ} \mathrm{C}$, respectively. The injected volume of mixed monosaccharide standards and sample hydrolyzates was $10 \mu l$. Identification of the monosaccharides in the extracts was carried out by comparing their retention times obtained for the authentic standards for seven monosaccharides (rhamnose, galactose, glucose, arabinose, xylose, mannose and glucuronic acid) in mobile phase at a concentration of $10 \mathrm{mg} / \mathrm{ml}$ under the same HPLC conditions.

The samples from $5 \%$ sulfuric acid pretreatment were taken out for fermentation experiments. Yeast fermentations were carried out in $250 \mathrm{ml}$ Erlenmeyer flasks at $\mathrm{pH} 4.6$ and $30^{\circ} \mathrm{C}$ consisting of, supplementary nutrients $0.9 \mathrm{~g} / \mathrm{l}\left(\mathrm{NH}_{4}\right)_{2} \mathrm{SO}_{4}$ and $0.375 \mathrm{~g} / \mathrm{l}$ yeast extract and the yeast inocula $\left(1.3 \times 10^{8} / \mathrm{ml}\right)$. The flasks were sealed with rubber stoppers through which hypodermic needles had been inserted for removal of $\mathrm{CO}_{2}$ produced during experimentation. The flasks were incubated for 48 hrs. Samples were withdrawn after 24 and 48 hrs of fermentation and the ethanol content and residual sugars were analyzed. Ethanol was measured following Caputi et al. (1968). Conversion rate of ethanol was calculated according to the ratio of ethanol produced and the initial sugar content in the fermentation medium using following equations.

Ethanol efficiency $(\%)=[($ Gram ethanol produced $) /($ Gram sugar used $)](0.511)(100)$

Ethanol yield $(\%)=($ Gram ethanol produced/gram sugar used $)(100)$

The constant 0.511 is the theoretical yield of ethanol produced from glucose

Experiments were conducted in triplicates. Results are expressed as mean with SE ( \pm ). 


\section{Results and Discussion}

In the Laurencia obtusa the concentration of ribose, galactose and arabinose were 16.91, 52.26 and $3.18 \mathrm{mg} / \mathrm{g}$ dry weight, respectively. Cystoseira compressa was found to contain fucose, xylose and mannose with concentration of 11.08, 46.83 and $31.66 \mathrm{mg} / \mathrm{g}$ dry weight, respectively. Fucose, ribose and glucose at a concentration of 48, 87.81 and $19.67 \mathrm{mg} / \mathrm{g}$ dry weight, respectively were present in the Colpomenia sinuosa. (Table1). The results indicate that the seaweeds are capable of production of bioethanol by hydrolysis and fermentation of sugars. Horn et al. (2000a) reported that fresh brown seaweed harvest contains about 15 - $20 \%$ carbohydrates of the total wet weight, which appear to be an appropriate substrate concentration for microbial conversion processes.

Table 1. Composition of polysaccharides isolated from extracts of seaweeds.

\begin{tabular}{lccc}
\hline \multirow{2}{*}{ Monosaccharides } & \multicolumn{3}{c}{ As amount (mg/g sample) } \\
\cline { 2 - 4 } & Laurencia obtusa & Cystoseira compressa & Colpomenia sinuosa \\
\hline Fucose & - & 11.08 & 48 \\
Ribose & 16.91 & - & 87.81 \\
Glucose & - & - & 19.67 \\
Galactose & 52.26 & - & - \\
Arabinose & 3.18 & - & - \\
Xylose & - & 46.83 & - \\
Mannose & - & 31.66 & - \\
\hline
\end{tabular}

Higher sugar content 42.84 g sugar /100 g dry biomass was extracted from Laurencia obtusa using $5 \% \mathrm{HCl}$ at $121^{\circ} \mathrm{C}$ for 20 minutes rather than the other different concentrations of acid and base (Fig.1a). The higher sugar concentration was associated with high acid concentration that was applicable to the acid, catalyzed the hydrolysis process. The catalyst activity was proportional to $\mathrm{H}$ concentration. The more hydrogen ions formed in the solution the more rapid the hydrolysis process occurred (Mosier et al. 2002).

The reducing sugars as by hydrolyzing Cystoseira compressa increased with increasing concentrations of $\mathrm{H}_{2} \mathrm{SO}_{4}, \mathrm{HCl}$ and $\mathrm{NaOH}$ at $121^{\circ} \mathrm{C}$ at 20 minutes whereas the highest amount of sugar was recorded in $3 \% \mathrm{H}_{3} \mathrm{PO}_{4}$ (30.51 g sugars/100g dry biomass) (Fig. 1b). The results of present study agree with Saxena et al. (2009) the dilute acid hydrolysis process is used to hydrolyze the biomass to sugars and is one of the oldest, simplest and most efficient methods. Dilute sulphuric acid is most acidable, and gives high hydrolysis yields (Mosier et al. 2002). Hydrolyzing Colpomenia sinuosa with $5 \% \mathrm{H}_{2} \mathrm{SO}_{4}$ and $\mathrm{H}_{3} \mathrm{PO}_{4}$ gave a higher reducing sugar production of 41.18 and $41.34 \mathrm{~g}$ sugar/100g dry biomass, respectively. Hydrolysis with $\mathrm{HCl}$ and $\mathrm{NaOH}$ showed different patterns, where $3 \% \mathrm{HCl}$ and $4 \% \mathrm{NaOH}$ concentrations produced the maximum amount of reducing sugars (26.41 and $19.76 \mathrm{~g}$ sugar/100g dry biomass, respectively) (Fig.1c). Jeihanipour and Taherzadeh (2009) reported that pretreatment with phosphoric acid results in a great improvement in the hydrolysis of the materials, but it is far from the results of alkali pretreatment by $\mathrm{NaOH}$.

Lack of lignin in seaweeds implies that the harsh pretreatment applied for release of fermentable sugars from lignocellulosic biomass is not required (Horn et al. 2000). 

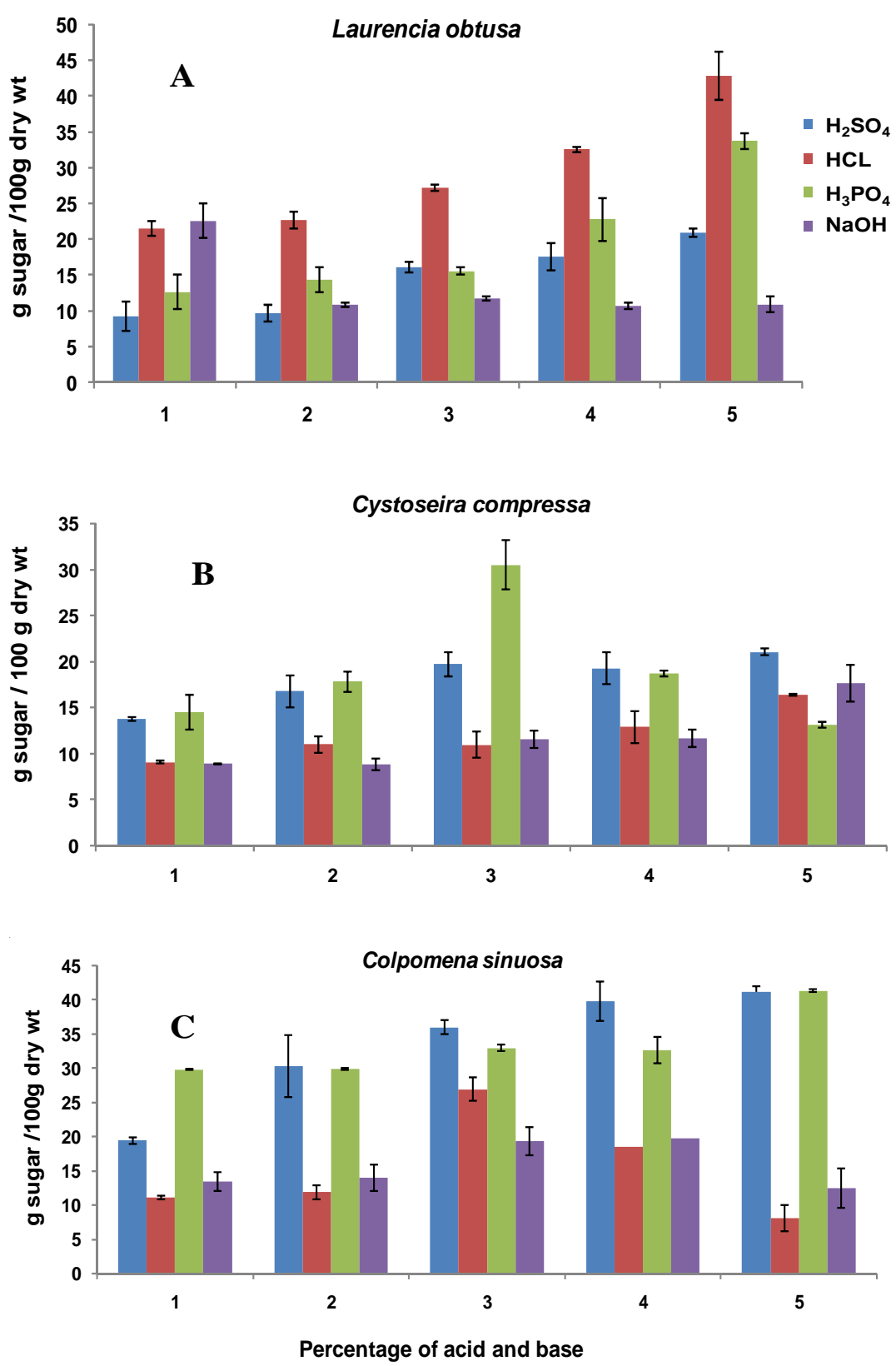

Figs 1A-C. Yield of reducing sugars by hydrolyzing seaweeds with acids and a base at $121^{\circ} \mathrm{C}$ for 20 minutes from (A) Laurencia obtusa, (B) Cystoseira compressa and (C) Colpomenia sinuosa.

Water soluble polysaccharides from red seaweed Apophloea lyallii were extracted with water at $100^{\circ} \mathrm{C}$ for $3 \mathrm{hrs}$. Extraction of the dried seaweed four times yielded a total of $63.6 \% \mathrm{w} / \mathrm{w}$ of polysaccharides (Watt et al. 2002). Carbohydrate content of red algae Pachymeniopsis lanceolata 
and Gelidium elegans were 60.15 and $51.3 \%$ (w/w), respectively and glucose contents were 45.9 and $15.3 \%(\mathrm{w} / \mathrm{w})$, respectively (Wi et al. 2009).

Effects of fermentation time on the conversion of sugars to bioethanol in acid pretreated Laurencia obtusa, Cystoseira compressa and Colpomenia sinuosa are shown in Table 2 and Fig. 2. Ethanol yield increased with the time in all tested algae. Reducing sugar produced by saccharification can be totally fermented by the yeast Saccharomyces cerevisiae. Sugar fermentation in Laurencia obtusa, Cystoseira compressa and Colpomenia sinuosa showed ethanol efficiency 68.48, 80 and 51.33\%, respectively. These results showed that not all sugars convert to bioethanol and this may be contributed to the reducing sugar released from cellulose that may convert further to hydroxymethyl furfural and soluble phenolic compounds which can inhibit the ethanol fermentation (Laser et al. 2002). High level ethanol of $0.146 \mathrm{~g} / \mathrm{g}$ of dry biomass of Laurencia obtusa biomass followed by Colpomenia sinuosa and Cystoseira compressa, respectively were found in (Fig. 2). The maximum alcohol content of $9.4 \%(\mathrm{v} / \mathrm{v})$ from red algae Pachymeniopsis lanceolata and 2.4\% (v/v) from Gelidium elegans, and alcoholic production of 74 and $65 \%$, respectively were recorded by Wi et al. (2009). The utilization of seaweeds for bioethanol production appears to be a sustainable and eco-friendly approach (John et al. 2011).

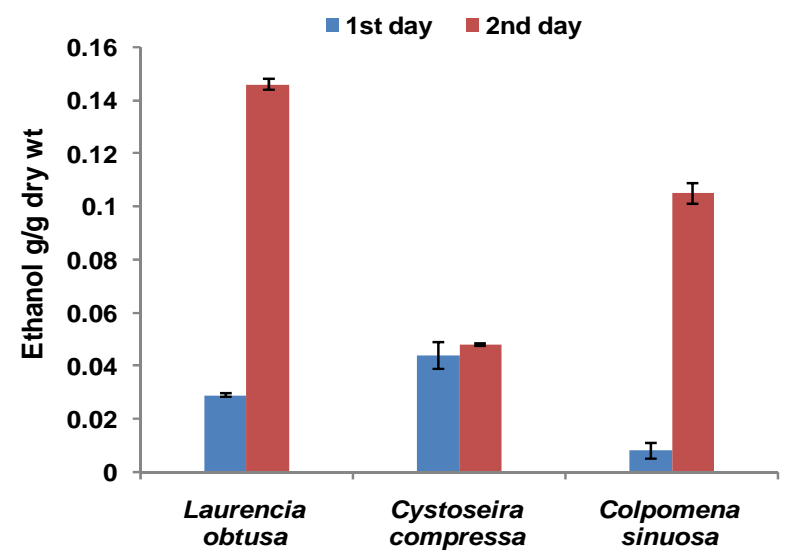

Fig. 2. Production of bioethanol by Saccharomyces cerevisiáe at $30^{\circ} \mathrm{C}$ using seaweed hydrolysates as the substrate.

Table 2. Ethanol yield after fermentation using seaweeds as feedstocks.

\begin{tabular}{llllll}
\hline \multirow{2}{*}{ Seaweeds } & \multirow{2}{*}{$\begin{array}{l}\text { Sugar in the } \\
\text { hydrolyzate }(\mathrm{g} / \mathrm{ml})\end{array}$} & \multicolumn{2}{c}{ Ethanol yield (\%) } & \multicolumn{2}{c}{ Efficiency (\%) } \\
\cline { 3 - 6 } & & $24 \mathrm{~h}$ & $48 \mathrm{~h}$ & $24 \mathrm{~h}$ & $48 \mathrm{~h}$ \\
\hline Laurencia obtusa & 0.0428 & 6.97 & 34.24 & 13.94 & 68.48 \\
Cystoseira compressa & 0.0210 & 21.09 & 40.04 & 42.18 & 80.00 \\
Colpomenia sinuosa & 0.0411 & 2.00 & 25.66 & 4.00 & 51.33 \\
\hline
\end{tabular}

Red and brown seaweed biomass could be viewed as good economic feedstocks and ecofriendly for bioethanol production through a series of pretreatments either alkaline or acidic hydrolysis followed by fermentation via yeast (S. cerevisiae). 


\section{References}

Caputi A, Ueda JM and Brown T 1968. Spectrophotometric determination of chromic complex formed during oxidation of alcohol. Am. J. Enol. Viticult. 19: 160-165.

Esteghlalian A, Hashimoto AG, Fenske JJ and Penner MH 1997. Modeling and optimization of the dilutesulfuric acid pretreatment of corn stover, poplar and switchgrass. Bioresource Technol. 59: 136-129.

Horn SJ, Aasen IM and Qstgaard K 2000a. Ethanol production from seaweed extract. J. ind. Microbial. Biotechnol. 25: 249-254.

John PR, Anisha GS, Nampoothiri and KM, Pandey A 2011. Micro and macroalgal biomass: A renewable source for bioethanol. Bioresource Technol. 1: 186-193.

Jeihanipour A and Taherzadeh MJ 2009. Ethanol production from cotton-based waste textiles. Bioresource Technol. 100: 1007-1010.

Kang DH, Lee JG, Park HS, Lee SH and Kang RS 2010. Liquefied extract of marine algae for producing bioethanol under high pressure and method for producing the same, United states. Patent application publication. 2010: Pup.NO.:US 2010/0041926 A1.

Krishnaveni S, Balasubramanian T and Sadasivam S 1984. Sugar distribution in sweet stalk sorghum. Food Chem. 15: 229-232

Kraan S 2010. Mass-cultivation of carbohydrate rich macroalgae, a possible solution for sustainable biofuel production, Mitig Adapt Strateg Glob Change 10: 9275-5.

Laser M, Schulman D, Allen SG, Lichwa J, Antal MJ and Lynd LR 2002. A comparison of liquid hot water and steam pretreatments of sugar cane bagasse for bioconversion to ethanol. Bioresource Technol. 81: 33-44

Mosier NS, Ladisch CM and Ladich MR 2002. Characterization of acid catalytic domains for cellulose hydrolysis and glucose degradation. Biotechnol and Bioeng. 6: 610-618.

Ohgren K, Bengtsson O, Gorwa-Grauslund M F, Galbe M, Hahn-Hagerdal B and Zacchi G 2006, Simultaneous saccharification and co-fermentation of glucose and xylose in steam-pretreated corn stover at high fiber content with Saccharomyces cerevisiae TMB3400. J. Biotechnol. 126: 488-498.

Ross AB, Jones JM, Kubacki ML, and Bridgeman T 2008. Classification of macroalgae as fuel and its thermochemical behavior. Bioresource Technol. 99: 6494-6504.

Roesijadi G, Jones SB, Snowden-Swan LJ, and Zhu Y 2010. Macroalgae as a Biomass Feedstock: A Preliminary Analysis," prepared for the U.S. Department of Energy under contract. DE-AC0576RL01830 by Pacific Northwest National Laboratory

Simpson AJ, and Kingery WL and Hatcher PG 2003. The identification of plant derived structures in humic materials using three-dimensional NMR spectroscopy. Environ. Sci. Technol. 37: 337-342.

Saxena RC, Adhikari DK and Goyal HB 2009. Biomass-based energy fuel through biochemical routes, Renew Sust. Energ. Rev. 13:167-178.

Singh A, Nigam PS and Murphy JD 2010. Mechanism and challenges in commercialisation of algal biofuels, Bioresource Technol. 102: 26-34.

Truus K, Vaher M and Taure I 2001. Algal biomass from Fucus vesiculosus (Phaeophyta): Investigation of the mineral and alginate components, Proc. Estonian Acad. Sci. Chem. 50: 95-103.

Watt DK, O'neill AS and Percy AE 2002. Brasch DJ, isolation and characterization of a partially methylated galacto-glucurono-xylo-glucan, unique polysaccharide from red seaweed Apophloea lyallii, Carbohydrate Polym. 50: 283-294.

Wi SG, Kim HJ, Mahadevan SA, Yang DJ and Bae HJ 2009. The potential value of the seaweed Ceylon moss (Gelidium amansii) as an alternative bioenergy resource, Bioresource Technol. 100: 6658-6660. 